\title{
Annotation
}

\section{Lactoferrin in human milk: its role in iron absorption and protection against enteric infection in the newborn infant}

The existence of lactoferrin was first reported by Sørensen and Sørensen, ${ }^{1}$ who observed a red protein fraction in human milk. The protein was first isolated by Groves ${ }^{2}$ from bovine and by Johansson ${ }^{3}$ from human milk, and subsequent studies showed that this protein (which has been variously called red milk protein, ekkrinosiderophilin, and lactotransferrin) is strikingly similar in many respects to the serum iron-binding protein transferrin. Human milk is unusually rich in lactoferrin, the normal concentration ranging from about $7 \mathrm{mg} / \mathrm{ml}$ in colostrum to not less than $1 \mathrm{mg} / \mathrm{ml}$ in mature milk. ${ }^{4}$ Although bovine colostrum also contains up to 5 $\mathrm{mg} / \mathrm{ml}$ lactoferrin, levels drop very rapidly as lactation proceeds, so that mature bovine milk normally contains only $20-200 \mu \mathrm{g} / \mathrm{ml} \mathrm{lactoferrin.}{ }^{5}$ Lactoferrin is now known to be present also in various other exocrine secretions (vaginal, nasal, bronchial, and intestinal), in pancreatic juice, and in the secondary granules of neutrophils. ${ }^{6-8} \mathrm{Al}-$ though there has been a great deal written about the structure, iron-binding properties, and in vitro biological activities of lactoferrin, no in vivo biological function has as yet been unequivocally established for it. The possible role of milk lactoferrin in iron absorption and in the control of the intestinal microflora of the newborn is discussed, as is the ability of lactoferrin to remain undegraded in the gastrointestinal tract of the infant.

\section{Structure and biochemical properties of lactoferrin}

Although lactoferrin has been identified in a wide variety of species ${ }^{4}$ almost all studies on the structure and iron-binding properties have been carried out with proteins of human or bovine origin. Lactoferrin closely resembles transferrin in that it consists of a single polypeptide chain of molecular weight $75000-90000,{ }^{9-10}$ and that it binds two ferric ions, together with the synergistic binding of two bicarbonate ions. ${ }^{11}$ It differs in being considerably more basic-the pI of transferrin is 5.9 , that of lactoferrin $\sim 9 \cdot 0^{12}$-and in having an even higher association constant for iron-binding. ${ }^{13}$ As a consequence lactoferrin, in the presence of a relatively lowaffinity iron chelator such as citrate, retains its iron below pH $4 \cdot 0$, whereas that of transferrin is lost as the $\mathrm{pH}$ is lowered from 6 to $5 .^{3}$ Further details of some of the physicochemical properties of lactoferrin are given by Parry and Brown. ${ }^{14}$

\section{Survival of lactoferrin in the gastrointestinal tract}

Discussion of the function of lactoferrin ingested by the breast-fed baby must take into account whether or not the protein reaches and can remain in the intestinal tract without being destroyed by gastric acidity or proteolytic activity. This aspect has been the subject of little discussion and of even less experimental work, and an attempt to assess the possible influence of these factors seems pertinent.

Although data vary somewhat, there seems to be general agreement that both acid and pepsin production in the newborn infant are low in relation to body weight compared with adult levels, and increase slowly with age. ${ }^{15-16}$ Certainly there is very little gastric proteolytic activity in newborn infants, ${ }^{17}$ but these infants can nevertheless digest milk proteins, presumably due to pancreatic protease production, which appears to be comparable with that of adults. ${ }^{18-19}$ This digestive ability increases with age, so that while newborn infants cannot completely digest milks containing $>1.3 \%$ protein, those of 4 months can digest milk containing $2.5 \%$ protein. ${ }^{20}$ This increase in overall digestive capacity during early life presumably occurs as a result of the increase in gastric proteolytic activity, given that pancreatic protease activity remains fairly constant. In this connection it should be pointed out that the discovery by Laskowski and Laskowski ${ }^{21}$ of a trypsin inhibitor in bovine colostrum has been quite unjustifiably extrapolated, even by the American Academy of Pediatrics, ${ }^{22}$ as indicating that an analogous inhibitor in human milk or colostrun would protect lactoferrin from digestion in the infant's gastrointestinal tract. In fact, no such inhibitor of this type, which is acid resistant, ${ }^{23}$ exists in human milk, which contains only low levels of an 
acid-labile (denatured below $\mathrm{pH} 6.0$ ) inhibitor analogous to serum $\alpha$-l-antitrypsin. ${ }^{24}$ It is unlikely that this small amount of labile trypsin inhibitor could significantly affect trypsin activity in the intestine of the human infant.

The most important feature of lactoferrin in regard to its susceptibility to proteolysis is the extreme lability of the iron-free (apo) form. In an in vitro study of the effect of trypsin on the apolactoferrin-mediated bacteriostatic action of bovine colostrum, it was found that bacteriostasis was lost more rapidly than was specific antibody activity in the colostrum, ${ }^{25}$ indicating that apolactoferrin is more susceptible to proteolysis than are immunoglobulins. Biochemical studies have shown that (bovine) apolactoferrin is rapidly degraded by trypsin to small peptides, whereas the iron-saturated form is relatively resistant to prolonged tryptic digestion, and gives rise only to large fragments which retain their iron-binding capacity. ${ }^{26}$ Pepsin, however, can partly digest the (human) ironsaturated protein, leaving a half-molecule containing one iron atom. ${ }^{27-28}$

In summary therefore, apolactoferrin is likely to be susceptible to digestion by proteolytic activity of either gastric or pancreatic origin, whereas the ironsaturated form may remain largely intact, at least as far as its iron-binding properties are concerned, until appreciable peptic activity is present. In addition, the rapid passage of the whey fraction from the stomach to the duodenum may further reduce the effectiveness of peptic digestion of lactoferrin, even in infants with significant pepsin activity.

\section{Antimicrobial activity of lactoferrin in the gut of the newborn infant}

The ability of lactoferrin to inhibit the growth of certain micro-organisms in vitro has been well documented. Most interest has focused on enteropathogenic strains of Escherichia coli ${ }^{29-31}$ although it may also inhibit Staphylococcus albus, ${ }^{32}$ Staphylococcus aureus, Pseudomonas aeruginosa, ${ }^{33}$ Bacillus stearothermophilus, Bacillus subtilis, ${ }^{34}$ and Candida albicans. ${ }^{35} \mathrm{~A}$ bactericidal effect of lactoferrin on Vibrio cholerae and Streptococcus mutans has also been reported. ${ }^{36}$ It is generally considered that the in vitro inhibition of $E$. coli requires the addition of bicarbonate to the milk or colostrum ${ }^{30} 37$ and the presence of specific antibodies, ${ }^{29}$ although good bacteriostatic activity in the absence of specific antibodies has also been reported. ${ }^{36} 38$ The need for added bicarbonate is probably due to the labilising effect on lactoferrin-bound iron of citrate ${ }^{39}$ which is present in milk and colostrum. ${ }^{30} 37$ Additional bicarbonate would enhance iron-binding by lactoferrin and prevent iron being made available to bacteria via the citrate complex. The role of antibody is more obscure. It may cause the inhibition of synthesis of microbial iron chelators, ${ }^{40}$ although it is not clear how this relates to the observation that the antibody responsible has a specificity directed towards a component sugar of the cell wall $\mathrm{O}$ - antigen. ${ }^{41}$

While there is little doubt that human milk does indeed tend to favour a lactobacillus or bifidus flora and suppress coliforms in the neonatal gut, in vivo evidence that lactoferrin is a contributory factor to this effect is scarce and certainly insufficient to justify the recent statement by the American Academy of Pediatrics that '. . . lactoferrin ... has an inhibitory effect on Escherichia coli in the intestine'. ${ }^{42}$ The experiments most widely cited as suggesting an in vivo antimicrobial effect for lactoferrin are those of Bullen et al. ${ }^{29}$ using guinea-pigs. Guinea-pig milk has a lactoferrin content similar to that of human milk. ${ }^{4}$ It was found that a challenge dose of $E$. coli administered to suckling guinea-pigs proliferated more rapidly in the intestines of animals dosed with haematin than in undosed animals. While this does indeed suggest that haematin caused enhanced growth of $E$. coli in the intestine, it cannot be assumed that this effect was directly due to saturation of the guinea-pig milk lactoferrin with iron, or indeed to the iron content of haematin at all. Haem iron is not available to nonhaem ironbinding proteins such as lactoferrin, and very little iron is released from haem by digestion. ${ }^{43-44}$ Haem is taken up intact by many micro-organisms, including $E$. coli, by pathways independent of nonhaem iron uptake. ${ }^{45}$ Furthermore, haem compounds may have effects unrelated to their properties as potential sources of iron for $E$. coli-for example, they alter the metabolism of various lactic acid bacteria, causing the production of cytochromes and, in at least one case, a pronounced reduction in lactic acid production. ${ }^{46-47}$ This might in itself, be sufficient to cause overgrowth of $E$. coli if intestinal lactobacilli were similarly affected. Haem compounds may also inactivate hydrogen peroxide, and could thus interfere with the peroxide-thiocyanate bactericidal mechanism of milk, ${ }^{5}$ and the bactericidal activity of milk phagocytes. ${ }^{48}$ However, the case for an in vivo protective role of lactoferrin has been considerably strengthened by the more recent work of Antonini et al..$^{49}$ These workers showed that the number of coliforms in the intestine of newborn guinea-pigs dosed with $E$. coli and fed cows' milk was lower if the milk was supplemented with ovotransferrin, the iron-binding protein of avian egg white which is structurally related to lactoferrin. Mortality of guinea-pigs infected with a high dose $\left(5 \times 10^{8}\right.$ cells) of $E$. coli during the first 24 hours of 
life was also lower in the group given ovotransferrinsupplemented milk, and was similar to the mortality among challenged animals allowed to suckle their mothers.

It must be remembered however that human and guinea-pig milks are unusually rich in lactoferrin whereas in other species-such as the cow and pig, where levels are high in colostrum but fall rapidly after the first few days of lactation-the levels in mature milk are insufficient to promote in vitro bacteriostasis. ${ }^{30}$ Dog milk, furthermore contains only traces of lactoferrin and transferrin, yet also contains appreciable amounts $(5 \mu \mathrm{g} / \mathrm{ml})$ of iron. ${ }^{4}$ It thus seems unlikely that lactoferrin could be important in protecting the young of these species from gastrointestinal infections. This is not to deny the potential antimicrobial function of the unusually high levels of lactoferrin in human milk, but does suggest that the principal function of this protein may be of a more subtle nature, and one which can be more easily related to these fundamental differences in iron and iron-binding protein content in milks of different species.

\section{Lactoferrin and iron absorption}

In adults, the capacity to absorb iron is closely related to intermediary iron metabolism, particularly erythropoiesis. In neonates however, iron absorption appears to be less dependent on intermediary iron metabolism, and is generally greater, in terms of percentage ingested iron absorbed, than in adults. The relatively efficient absorption of breastmilk iron ${ }^{50-51}$ and the close biochemical relationship between lactoferrin and transferrin would tend to suggest that lactoferrin, like transferrin, possesses an iron-transport role and the possibility that it serves to transport iron to the intestinal mucosa in a readily absorbed form. Such a suggestion is not however supported by the rather limited amount written on the role of lactoferrin in iron absorption. McMillan et al. ${ }^{52}$ showed that the addition of lactoferrin, presumably iron-saturated (the iron content given $(140 \mathrm{mg} / \mathrm{g})$ is actually 100 -fold higher than that of saturated lactoferrin) to a lactoferrin-free simulated human milk administered to adults did not increase iron absorption. De Laey et al. ${ }^{53}$ showed that apolactoferrin actually inhibited iron uptake by rat and guinea-pig everted duodenal sacs, and $\mathrm{Fe}_{2}$-lactoferrin was without effect. De Vet and Van $\mathrm{Gool}^{54}$ demonstrated a negative relationship between duodenal lactoferrin concentration and iron absorption in adults. Both groups suggested that lactoferrin may serve to protect the mucosa against excessive uptake of heavy metal ions, and Van Vugt et al..$^{55}$ have proposed that the increased biliary lactoferrin con- centrations observed in anaemic rabbits serve as an additional control of iron absorption in conditions where other controls have been relaxed to permit increased absorption. This mechanism could be of importance in the term newborn infant, who has both a high potential for iron absorption and replete iron stores during the immediate postnatal period, when milk lactoferrin levels are at their highest. Indeed, Cavell and Widdowson ${ }^{56}$ have shown that during the first week of life breast-fed infants excrete 10 times more iron than they absorb. In this study 10 babies aged 5-8 days excreted daily on average $1.12 \mathrm{mg} / \mathrm{kg}$ iron. The mean daily milk intake was $160 \mathrm{ml} / \mathrm{kg}$, from which it can be calculated that if the excreted iron were all bound by milk lactoferrin, a concentration of about $5 \mathrm{mg} / \mathrm{ml}$ in the milk would be required, which is close to values observed by Masson and Heremans ${ }^{4}$ during the first week of lactation. The origin of this excreted iron is unknown, although the bile seems a likely source, and lactoferrin may thus serve to prevent this iron being reabsorbed. This postnatal unloading of iron may serve to reduce susceptibility to infection ${ }^{57}$ or even, as suggested by Neffgen and Rakušan ${ }^{58}$ to stimulate myocardial growth.

McMillan et al..$^{52}$ have shown that the iron in human milk, despite the high lactoferrin content, is more readily absorbed than iron from a simulated human milk of comparable iron content, and furthermore this availability was not affected by boiling the milk, which would denature lactoferrin. However, these studies were performed in adults, whose capacity to digest lactoferrin would be greater than that of infants, and furthermore there were significant differences in mineral content between the simulated and human milks, ${ }^{59}$ which might affect iron availability. Likewise it must be remembered that the infants studied by Saarinen et al. ${ }^{51}$ in whom high bioavailability of breast-milk iron was demonstrated using the extrinsic tag method, were all over 6 months old and would also have had a relatively well developed digestive system. Nevertheless, a tracer dose of iron administered after a 3-hour fast was slightly less well absorbed than a similar dose administered during a breast-milk feed ${ }^{51}$ suggesting that breast milk does contain factors which actively promote iron absorption. It is perhaps possible to envisage two opposing effects operating in the breast-fed infant: in the newborn, iron absorption is relatively poorly controlled, but high lactoferrin levels in the milk and low gastrointestinal proteolytic activity tend to prevent iron becoming available for absorption. As the infant matures his need for exogenous iron increases, milk lactoferrin levels decrease and proteolytic activity increases, resulting in progressively more iron being released from 
lactoferrin. Once released, absorption of this iron is facilitated by other factors present in human milk, as suggested by Saarinen et al..$^{51}$ It may be more than coincidental that lactoferrin levels are highest in the milk of man and the guinea-pig, both of whose young grow notably more slowly than those of other species of comparable size, and whose need for exogenous iron will be relatively retarded. In species whose young grow rapidly-for example, rabbit, rat, pig, and cow-lactoferrin levels are, except in colostrum, low or nonexistent ${ }^{4}$ and would not significantly control the absorption of milk iron which would be required to meet the rapidlyincreasing blood volume. It is noteworthy in this respect that newborn rats, unlike human infants, ${ }^{60}$ absorb virtually $100 \%$ of milk iron. Some basis for the hitherto unexplained erratic distribution of lactoferrin in the milk of different species may thus be provided by this hypothesis. However, further experimental work, preferably using purified lactoferrin in newborn animals or babies will be required to test the hypothesis that lactoferrin in milk serves to control iron absorption in the neonate.

\section{Conclusions}

This annotation has attempted to discuss critically the data on the role of milk lactoferrin in antimicrobial activity and iron absorption. Considerable attention has been focused on the role of lactoferrin in protecting the neonate against gastrointestinal infections, but further in vivo experimental data are needed before such a function can be considered as unequivocally established. More neglected, but perhaps more deserving of further study, is the role of lactoferrin in iron absorption. In this annotation it is proposed that a major function of lactoferrin may be to control iron absorption, and perhaps even to facilitate excretion of iron in the immediate postnatal period. Although this theory needs to be backed by direct experimental data, it has the attraction of providing a rational explanation of the curious variation in lactoferrin levels in milks of different species.

I thank Professor F Cockburn, Department of Child Health, University of Glasgow, and Dr B Reiter, National Institute for Research in Dairying, Reading, for reviewing the manuscript.

\section{References}

1 Sørensen M, Sørensen S P L. The proteins in whey. $C R$ Lab (Carlsberg) [Ser Chim] 1939; 23: 55-9.

2 Groves M L. The isolation of a red protein from milk. J Am Chem Soc 1960; 82: 3345-50.
3 Johansson B. Isolation of an iron-containing red protein from human milk. Acta Chem Scand 1960; 14: 510-2.

4 Masson P L, Heremans J F. Lactoferrin in milk from different species. Comp Biochem Physiol (B) 1971; 39: 119-29.

5 Reiter B. Review of non-specific antimicrobial factors in colostrum. Ann Rech Vet 1978; 9: 205-24.

- Masson P L, Heremans J F, Dive C. An iron-binding protein common to many external secretions. Clin Chim Acta 1966; 14: 735-9.

7 Masson P L, Heremans J F, Schonne E, Crabbé P A. New data on lactoferrin, the iron-binding protein of secretions. Protides Biol Fluids 1968; 16: 633-8.

8 Masson P L, Heremans J F, Schonne E. Lactoferrin, an iron-binding protein in neutrophilic leukocytes. $J$ Exp Med 1969; 130: 643-58.

- Querinjean P, Masson P L, Heremans J F. Molecular weight, single-chain structure, and amino-acid composition of human lactoferrin. Eur J Biochem 1971; 20: $420-5$.

10 Weiner R E, Szuchet S. The molecular weight of bovine lactoferrin. Biochim Biophys Acta 1975; 393: 143-7.

11 Masson P L, Heremans J F. Metal-combining properties of human lactoferrin (red milk protein). I. The involvement of bicarbonate in the reaction. Eur J Biochem 1968; 6: 579-84

12 Malamud D, Drysdale J W. Isoelectric points of proteins: a table. Anal Biochem 1978; 86: 620-47.

13 Aisen P, Leibman A. Lactoferrin and transferrin; a comparative study. Biochim Biophys Acta 1972; 257: 314-23.

14 Parry R M, Brown E M. Lactoferrin conformation and metal binding properties. Adv Exp Med Biol 1974; 48: 141-60.

15 Evans $P$, MacKeith $R$. Infant feeding. London: Churchill, 1954.

16 Agunod M, Yamaguchi N, López R, Luhby A L, Glass G B J. Correlative study of hydrochloric acid, pepsin, and intrinsic factor secretion in newborns and infants. Am J Dig Dis 1969; 14: 400-14.

17 Mason S. Some aspects of gastric function in the newborn. Arch Dis Child 1962; 37: 387-91.

18 Hadorn B, Zoppi G, Shmerling D H, Prader A, McIntyre I, Anderson C M. Quantitative assessment of exocrine pancreatic function in infants and children. $J$ Pediatr 1968; 73: 39-50.

19 Lindberg T. Proteolytic activity in duodenal juice in infants, children, and adults. Acta Paediatr Scand 1974; 63: 805-8.

20 Hirata Y, Matsuo T, Kokubu H. Digestion and absorption of milk proteins in infant's intestine. Kobe J Med Sci $1965 ; 11$ : 103-9.

21 Laskowski M, Jr, Laskowski M. Crystalline trypsin inhibitor from colostrum. J Biol Chem 1951; 190: 563-73.

22 American Academy of Pediatrics Committee on Nutrition. Relationship between iron status and incidence of infection in infancy. Pediatrics 1978 ; 62: 246-50.

23 Piñeiro A, Ortega F, Uriel J. Trypsin inhibitor from cow colostrum. Isolation, electrophoretic characterisation, and immunologic properties. Biochim Biophys Acta 1975; 379: 201-6.

24 Barkholt Pedersen V, Keil-Douhá V, Keil B. On the properties of trypsin inhibitors from human and bovine colostrum. FEBS Lett 1971; 17: 23-6.

25 Brock J H, Piñeiro A, Lampreave F. The effect of trypsin and chymotrypsin on the antibacterial activity of complement, antibodies and lactoferrin, and transferrin in bovine colostrum. Ann Rech Vet 1978; 9: 287-94.

26 Brock J H, Arzabe F, Lampreave F, Piñeiro A. The effect of trypsin on bovine transferrin and lactoferrin. Biochim Biophys Acta 1976; 446: 214-25. 
27 Line W F, Sly D A, Bezkorovainy A. Limited cleavage of human lactoferrin with pepsin. Int J Biochem 1976; 7: 203-8.

28 Bluard-Deconinck J-M, Williams J, Evans R W, Van Snick J, Osinski P A, Masson P L. Iron-binding fragments from the $N$-terminal and $C$-terminal regions of human lactoferrin. Biochem $J$ 1978; 171 : 321-7.

29 Bullen J J, Rogers H J, Leigh L. Iron-binding proteins in milk and resistance to Escherichia coli infection in infants. Br Med J 1972; i: 69-75.

30 Reiter B, Brock J H, Steel E D. Inhibition of Escherichia coli by bovine colostrum and post-colostral milk. II. The bacteriostatic effect of lactoferrin on a serum-susceptible and serum-resistant strain of $E$. coli. Immunology 1975; 28: 83-95.

31 Spik G, Cheron A, Montreuil J, Dolby J M. Bacteriostasis of a milk-sensitive strain of Escherichia coli by immunoglobulins and iron-binding proteins in association. Immunology 1978; 35: 663-71.

32 Masson P L, Heremans J F, Prignot J J, Wauters G. Immunohistochemical localisation and bacteriostatic properties of an iron-binding protein from bronchial mucus. Thorax $1966 ; 21$ : 538-44.

83 Masson P L, Heremans J F. Studies on lactoferrin, the iron-binding protein of secretions. Protides Biol Fluids 1966; 14: 115-24.

34 Oram J D, Reiter B. Inhibition of bacteria by lactoferrin and other iron-chelating agents. Biochim Biophys Acta 1968; 170: 351-65.

${ }^{35}$ Kirkpatrick C H, Green I, Rich R R, Schade A L. Inhibition of growth of Candida albicans by iron-unsaturated lactoferrin: relation to host defense mechanisms in chronic mucocutaneous candidiasis. J Infect Dis $1971 ; 124: 539-44$.

36 Arnold R R, Cole R M, McGhee J R. A bactericidal effect for human lactoferrin. Science 1977; 197: 263-5.

37 Griffiths E, Humphreys J. Bacteriostatic effect of human milk and bovine colostrum on Escherichia coli. Importance of bicarbonate. Infect Immun 1977; 15: 396-401.

${ }^{38}$ Law B A, Reiter B. The isolation and bacteriostatic properties of lactoferrin from bovine milk whey. $J$ Dairy Res 1977; 44: 595-9.

39 Aisen P, Leibman A. Citrate-mediated exchange of $\mathrm{Fe}^{3+}$ among transferrin molecules. Biochem Biophys Res Commun 1968; 32: 220-6.

40 Rogers $H$ J. Iron-binding catechols and virulence in Escherichia coli. Infect Immun 1973; 7: 445-56.

41 Fitzgerald S P, Rogers H J. Bacteriostatic effect of serum on Escherichia coli $\mathrm{O}$ 111: elucidation of the antibodybinding site (abstract). Proc Soc Gen Microbiol 1976; 3: 110.

42 American Academy of Pediatrics Committee on Nutrition. Breast feeding. Pediatrics 1978; 62: 591-601.

43 Sanford R. Release of iron from conjugates in food. Nature $1960 ; 185$ : 533-4.

44 Conrad M E, Weintraub L R, Sears D A, Crosby W H. Absorption of hemoglobin iron. Am J Physiol 1966; 211 : 1123-30.
45 Jacobs N J. Biosynthesis of heme. In Neilands J B, ed. Microbial iron metabolism. New York: Academic Press, 1974: 125-48.

46 Sijpesteijn A R. Induction of cytochrome formation and stimulation of oxidative dissimilation by hemin in Streptococcus lactis and Leuconostoc mesenteroides. Antonie van Leeuwenhoek 1970; 36: 335-48.

47 Van der Weil-Korstanje J A A, de Vries W. Cytochrome synthesis by bifidobacterium during growth in media supplemented with blood. J Gen Microbiol 1973; 75: 417-9.

48 Pitt J, Barlow B, Heird W C. Protection against experimental necrotizing enterocolitis by maternal milk. I. Role of milk leukocytes. Pediatr Res 1977; 11 : 906-9.

49 Antonini E, Orsi N, Valenti P. Effetto delle transferrine sulla patogenicità delle Enterobacteriaceae. G Malatt Infett Parassit 1977; 29 : 481-9.

50 McMillan J A, Landaw S A, Oski F A. Iron sufficiency in breast-fed infants and the availability of iron from human milk. Pediatrics 1976; 58: 686-91.

51 Saarinen U M, Siimes M A, Dallman P R. Iron absorption in infants: high bioavailability of breast milk iron as indicated by the extrinsic tag method of iron absorption and by the concentration of serum ferritin. J Pediatr 1977; 91 : 36-9.

52 McMillan J A, Oski F A, Lourie G, Tomarelli R M, Landaw S A. Iron absorption from human milk, simulated human milk, and proprietary formulas. Pediatrics 1977; 60: 896-900.

${ }^{53}$ De Laey P, Masson P L, Heremans J F. The role of lactoferrin in iron absorption. Protides Biol Fluids 1968; 16: 627-32.

54 De Vet B J C M, Van Gool J. Lactoferrin and iron absorption in the small intestine. Acta Med Scand 1974; 196: 393-402.

55 Van Vugt H, Van Gool J, Ladiges N C J J, Boers W. Lactoferrin in rabbit bile: its relation to iron metabolism. QJ Exp Physiol 1975; 60 : 79-88.

${ }^{56}$ Cavell P A, Widdowson E M. Intakes and excretions of iron, copper, and zinc in the neonatal period. Arch Dis Child 1964; 39: 496-501.

57 Weinberg E D. Iron and infection. Microbiol Rev 1978; 42: 45-66.

58 Neffgen J F, Rakušan K. Iron supplementation in suckling rats: its effect on the heart. Recent Adv Stud Cardiac Struct Metab 1975; 10: 707-16.

59 Brock J H. Letter: Human milk and iron absorption. Pediatrics 1978; 62: 440-1.

60 Ezekiel E. Intestinal iron absorption by neonates and some factors affecting it. J Lab Clin Med 1967; 70: 138-49.

J H BROCK

Department of Bacteriology and Immunology, Western Infirmary, Glasgow G11 6NT 